\title{
An Evaluation of Household Accounting in Mauritius
}

\author{
Vidisha Gunesh Ramlugun \\ Faculty of Law and Management \\ University of Mauritius \\ Dineshwar Ramdhony (Corresponding author) \\ Faculty of Law and Management \\ University of Mauritius \\ Email: d.ramdhony@uom.ac.mu \\ Bissoon Poornima \\ Faculty of Law and Management \\ University of Mauritius
}

Received: July 15, 2016 Accepted: July 31, 2016 Published: August 04, 2016

doi:10.5296/ijafr.v6i2.9840 URL: http://dx.doi.org/10.5296/ijafr.v6i2.9840

\begin{abstract}
The study investigates the accounting practices of Mauritian households. We explore the likelihood of these practices by administering a questionnaire among 120 random family units. More particularly, four areas of accounting are emphasised- budgeting, record keeping, decision-making and long term financial planning. The findings mainly reveal that household accounting is used in Mauritian homes. Factors such as the risk of debt, tax calculation and important events as marriage, death and birth influence these usages. We suggest that while households are not profit clusters, it is an area of significant interest and therefore deemed to be an area worth of academic study.
\end{abstract}

Keywords: Household accounting, Budgeting, Record keeping, Decision making and financial planning 


\section{Introduction}

Household accounting practices have not received great attention among accounting scholars; little is known of how accounting is used in the home. It would seem that the home is not viewed as an area worthy of academic study due to the preoccupation with concerns of the "glamorised and professional world of the public" (Walker and Llewellyn, 2000). Nonetheless, research has proved that accounting skills can cross the work/home boundary. In addition, as argued by Janudin and Mohamad (2005), the home is also a locus of production and consumption, and consequently can be compared to a small firm. It has also been argued that "given the complex realities of managing a household it is not surprising to discover that the home is a place where we may locate the performance of rational practices such as accounting, and we may identify manifold structures of accountability"1

Basically, accounting relates to the recording, classifying and summarizing of data and communicating financial information and has been defined as "the language of business", Wood (2005). Moreover, accounting affects people in their personal lives in the same way as it affects large businesses. For instance, accounting ideas are used at home where the household's income is planned by writing down a plan, known as a budget, or by simply keeping it in mind. Research in Japan found that household accounts were promoted as an important tool for improving savings levels (Komori and Humprey, 2000). Accounting in effect became one of the ways to create a set of standards for shaping lifestyle. Furthermore, common values and objectives among family members can be set up through accounting. For instance, accounting has aided to highlight the value of women's contribution in the home. Likewise, Llewellyn and Walker (2000) have argued that a lack of accounting for "housework" makes it rather invisible, meaning that housewives can find it difficult to gain "a positive sense of self". It has also been observed that accounting techniques are presented as devices which are conducive to the attainment of an improved quality of life (Walker and Llewellyn, 2000). Froudet al (2000) explain that as households increase and their difference becomes more accentuated especially in industrialised countries, the household must be increasingly analysed rather than be regarded as a standardized and stable group. Thus, accountants should use their skills in assisting to build a new social accounting which aids to understand the workings of the whole economy and helps in policy-making, especially regarding household issues.

Academic study of accounting at home is a developing area, and to date, there have been scarcely any studies profiling household accounting in Mauritius. Furthermore, the essence of the study also arises because of the high indebtedness of the Mauritian population. For instance, the National Economic and Social council in its recent report declares that "Mauritian families have, since late, been seen to be living beyond what their means allow" ${ }^{3}$.Thus, this paper purports to explore the possibility of accounting practices in

\footnotetext{
${ }^{1}$ See Walker, S. and Llewellyn, S. (2000), “Accounting at home; some interdisciplinary perspectives", Accounting, Auditing \& Accountability Journal, pp 425

${ }^{2}$ See Llewellyn, S. and Walker,(2000) "Accounting as an interface activity: the home, the economy and gender", Critical Perspectives on Accounting. Pp 18

${ }^{3}$ See NESC report "Managing Indebtedness and Household Budgets for Better Living", April 2011
} 


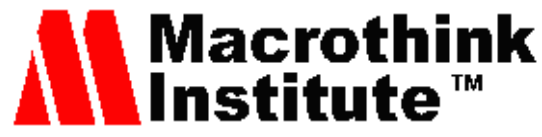

International Journal of Accounting and Financial Reporting ISSN 2162-3082

Mauritian households. The main objective of the paper is to evaluate household accounting in Mauritius. As the field of accounting is quite vast, four broad areas will be considered: budgeting, record-keeping, decision making and long-term financial planning. Different aspects such as the use of these practices in the homes, the benefits and drawbacks associated with household accounting will also be addressed.

This paper is organized as follows: after the introduction, the second section provides findings of previous studies. The third section discusses the methodology used. The fourth section which is on empirical data analysis, discusses the results and the findings of this study. Finally, the study concludes with a discussion of the limitations of the study, and future research in this field advocated.

\section{Literature Review and Hypotheses}

One of the main reasons for the lack of previous attention to household accounting is that accountancy has conventionally been regarded as a vocation which is reserved to the workplace where the customers of accounting comprise the owners and managers of organisations (Walker and Llewellyn, 2000). Despite the recurrent advices of observers such as Fagerberg (1954), who argued that it was "high time ... that a rationale and philosophy be developed concerning the accounts of individuals" , the use of accounting technologies by families in the private sphere of the household has been overshadowed by concerns with accounting in the workplace. The subsequent authors equally assert that accounting is not only restricted to the business world; it is likewise well established in the household although the household accounting practices may be effectively derived from the working place. Haskins (1984) acknowledges that accounting and finance are not limited to the place of work; these subjects are also vital features of the home life. Carnegie and Walker (2007a) also contend that beyond the public world of work, the home provides an area for investigating accounting in daily life. There are indications that the sources of accounting knowledge applied to the household were gained in the public world of work (Llewellyn and Walker, 2000). Account keeping along business lines was also proposed by some early twentieth century commentators: "We are becoming a society of businesspeople. We speak in jargon derived from the business world. The buzz word these days ... is "personal productivity", as if the home itself - maybe life itself - were best viewed as a business" (Levy, 1989). Similarly, Northcott and Doolin (2000) revealed that there is little difference between the practices of accountants and those of lay people. The four most prominent household accounting practices emphasised by many authors are: record keeping, budgeting, decision-making and long-term financial planning. Northcott and Doolin (2000) suggest that these simple accounting practices are used in the home to serve numerous purposes.

\subsection{Budgeting}

Nickell et al (1976) and Oppenheim (1976) emphasise that budgeting is often advocated as an important feature of daily life; a method which eases control over the financial destiny of the individual or the family. Many features of budgetary practice mentioned in literature are

\footnotetext{
${ }^{4}$ See Fagerberg, D. (1954), "Spotlight on personal accounting", The Accounting Review, pp. 355
} 
geared towards the control of cash flows. All, nevertheless, highlighted the timing of cash flows as the primary issue (Northcott and Doolin, 2000). The salary, the household major source of income, is normally received on a monthly basis. Berthoud and Kempson (1992) also aver that the rate at which income is earned impacts the selection of the budgeting period and hence the latter is also linked to occupational rank.

The occurrence of important events in the life of a family and related financial limitations influence the level to which budgeting is undertaken and the incidence of budget examination. These incidents have a bearing on the household budget and accordingly people may modify their method of money management (Whyleyet al., 1997). Furthermore, Janudin and Mohamad (2005) establish that during budget preparation, household prioritise saving and provide for contingency plans in the event of unforeseen circumstances.

\subsection{Record keeping}

Carnegie and Walker (2007a) maintain that accounting in Australian homes focused on maintaining records of routine transactions as opposed to the preparation of budgets and financial statements. Janudin and Mohamad (2005) state that their research from record keeping activities confirms that the aim of record keeping is similar to accounting objective which is for reference purposes.

\subsection{Decision making process}

Northcott and Doolin (2000) aver that the decision making process seems to be directed to three principal areas namely the determination of saving purposes, short and long term financing choices and decisions about major purchases such as the family home, cars, holidays and consumer durable goods. Hopper (1995) indicates that while women are involved in many facets of family financial behaviour, men generally exhibit the heaviest contribution in financial decisions. Janudin and Mohamad (2005) argue that for decision making process, household decisions become more important when greater sums of money are involved. It is normally the family leader who has the final say on financial decision making and the main criterion on which decision is based is cash.

\subsection{Long Term Financial Planning}

This part of home accounting has not earned much attention from the accounting researchers. Usually, households have short-term preferences that decrease their propensity to be involved in long term financial planning. Findings from research also indicate that households aspire to live within their means in both the short and the long term (Northcott and Doolin, 2000).

While budgeting, record-keeping, decision making and long-term financial planning were all patent aspects of home accounting practice, their specific nature and analysis in the home differed from what might be expected in businesses (Northcott and Doolin, 2000). Furthermore, Thaler (1992) claimed that home accountants seem to live with challenging and fast changing short and long-term goals and their accounting practices are, occasionally, subject to amendment to cope with these changes. Moreover, new forms of money, such as credit cards and debit cards, telephone and internet banking may be changing the accounting 
practices which take place within homes (Pahl 2000).

\subsection{Factors influencing household accounting}

Walker and Llewellyn (2000) claim that crucial events in life such as marriage, death and birth may lead to the commencement of household and personal accounting while Connor (2004)avers that widowhood, with the subsequent management of personal finances and the perpetuation of a deceased husband's business, has long been acknowledged as a catalyst for home accounting. Mc Rae (1997) propounds that the regression of the welfare State means that individuals are increasingly accountable for their own long-term financial security.

Piorkowsky and Friedrich-Wilhelms (2000) revealed variations in the extent of household accounting in Germany according to gender, region, household structure, age, occupation and employment status. Similarly, Northcott and Doolin (2000) claim that ideas to home financial management were habitually learned from parents where they were intentionally passed to children.

Hopwood (1994) and Walker and Llewellyn (2000) stated that the household enables an understanding of accounting and gender in daily situations. Research suggests that while areas of financial responsibility were characterised by gender, there was little evidence of such issue in household accounting between spouses as has been found to be the case in Britain (Walker, 1998). Household accounting in Australia was undertaken by both women and men of the middle and rich classes (Carnegie and Walker, 2007b).

Komori and Humphrey (2000) also allege that gendered differentiation is not as apparent as in countries such as Japan. A fair proportion of men are involved in household accounting as they want to find the space to enjoy a more involved and caring family life. Piorkowsky and Friedrich-Wilhelms (2000) argue that in Germany, among those households where there existed a distribution of tasks it was principally women who were accountable for the daily recording of income and expenditure while men were responsible for accounting in relation to assets and liabilities. Where electronic accounting systems were used it was mostly men who were responsible for record keeping.

While the prescriptive literature on household management is targeted towards women and many instances are identified of women engaging in this practice, it appears that men are also inclined to keep household and personal accounts. Nonetheless, gender is not the only factor influencing home accounting; other factors such as age and occupation also play a significant role.

\subsection{Hypotheses}

Rationally, one would expect to perceive more advanced accounting practices among family units with higher levels of education. Similarly, the type of work determines the regularity of income (Chowa, 2006). Based on the above argument, we develop the following hypothesis:

H1: Household accounting is influenced by the level of education

Furthermore, one would expect that households earning a lower level of income would be 


\section{MlMacrothink}

International Journal of Accounting and Financial Reporting

ISSN 2162-3082

2016, Vol. 6, No. 2

more inclined to manage their expenditure. In addition Pahl (2000) aver that poor couples earning lower incomes have to monitor their financial situations more than affluent couples; the less money there is, the more firmly it has to be managed and the more difficult and demanding is the job of the family accountant. The following is therefore established:

H2: Household accounting is influenced by level of income

Mixed results have been published in existing literature about how gender impact on household accounting. To verify whether the same has an influence on home-accounting in Mauritius, we develop the following hypotheses:

H3: Household accounting is influenced by gender.

Furthermore, it is also acknowledged in literature that geographic profiles have an impact on account keeping. For instance, the study by Piorkowsky (2000) reveals that keeping accounting records on aregular basis was more common in the NeueLaÈnder (new state) than inthe AlteLaÈnder (old state). We try to establish a similar relationship by arguing that family units in the urban region would be more disposed towards accounting practices than rural families, more specifically, urban households would adopt more advanced accounting practices. Accordingly, it can be hypothesized that:

H4: Household accounting is influenced by geographical location

\section{Methodology}

The main objective of this paper is to evaluate four broad areas of accounting practices in Mauritian households. For the purpose of the methodology, four accounting areas formed the focus of our investigation. The categories were drawn from those identified by Northcott and Doolin (2000).

\subsection{Sampling}

The data collection instrument comprised of a six section questionnaire administered to a sample of 120 households $^{5}$. A stratified random sampling has been adopted whereby the households were chosen depending on their place of residence in order to ensure that a representative sample of Mauritius is chosen. As Mauritius is divided in regions namely urban and rural, the following sample was chosen.

Table 1: : Sample selection

\begin{tabular}{|l|l|l|l|l|}
\hline $\begin{array}{l}\text { Place } \\
\text { residence }\end{array}$ & Total number of households & $\begin{array}{l}\text { Percentage } \\
\text { households }\end{array}$ & $\begin{array}{l}\text { Number in } \\
\text { sample }\end{array}$ \\
\hline Urban & 130918 & $45 \%$ & 54 \\
\hline Rural & 158252 & $55 \%$ & 66 \\
\hline Total & 289170 & $100 \%$ & 120 \\
\hline
\end{tabular}

\footnotetext{
${ }^{5}$ At the time of the survey, there were about 290000 households in Mauritius; it would be extremely time consuming, expensive and difficult to investigate the accounting practices of all these households. Consequently, a sample of 120 households was chosen
} 


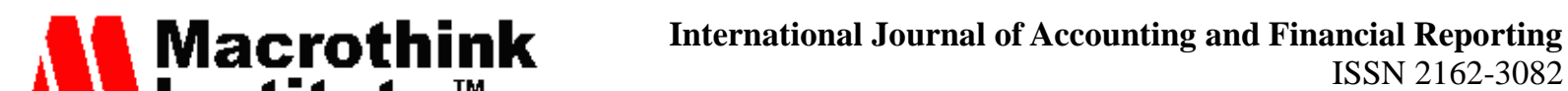 2016, Vol. 6, No. 2}

\subsection{Questionnaire construction}

Items of the questionnaire were based on relevant literature in the area. Part A comprised of general information, and investigating on the various benefits, drawbacks and motives of household accounting while part B, C D and E measured the four accounting practices namely budgeting, record keeping, decision making and long term financial planning. The last section of the questionnaire related to personal information of home accountants: gender, age, educational background, occupation, place of residence, household income and number of members in the household. To assess the various benefits, drawbacks and motives of household accounting, different options were proposed on a 5 point Likert scale where 1 meant strongly agree and 5 strongly disagree. Since all questionnaires were hand- collected, this endured a response rate of $100 \%$. The questionnaires were pilot tested on a small number of respondents.

\subsection{Data Analysis}

Data collected was analyzed using version 16 of IBM SPSS Statistics and The Pearson Chisquare statistic was used to test the hypotheses. Factor analysis was performed on the benefits and drawbacks of household accounting.

\section{Discussion of Findings}

The eight characteristics of the 120 households and the home accountants are established below in Table 2 below.

\begin{tabular}{|c|c|}
\hline Characteristics & $\begin{array}{l}\text { Responses } \\
\text { (\%) }\end{array}$ \\
\hline $\begin{array}{l}\text { Gender: Male } \\
\text { Female }\end{array}$ & $\begin{array}{l}73 \\
27\end{array}$ \\
\hline $\begin{array}{l}\text { Any member of the household has studied accounting at least up to School } \\
\text { Certificate: Yes } \\
\text { No }\end{array}$ & $\begin{array}{l}77 \\
23\end{array}$ \\
\hline $\begin{array}{r}\text { Number of members in the house: }<4 \\
4 \\
5 \\
>5\end{array}$ & $\begin{array}{l}17 \\
44 \\
28 \\
11\end{array}$ \\
\hline $\begin{array}{l}\text { Total mo nthly inco me of Mauritian households: } \\
\qquad \begin{array}{l}\text { <s } 10000 \\
\text { Rs } 10001-\operatorname{Rs} 15000 \\
\text { Rs } 15001-\operatorname{Rs} 20000 \\
>\text { Rs } 20001\end{array}\end{array}$ & $\begin{array}{l}13 \\
21 \\
18 \\
48\end{array}$ \\
\hline $\begin{array}{c}\text { Location of ho usehol ds: Village } \\
\text { Town }\end{array}$ & $\begin{array}{l}55 \\
45\end{array}$ \\
\hline
\end{tabular}

As can be seen from the table, the majority of respondents have accounting knowledge. Four members are quite common in Mauritian households. In terms of household income, $40 \%$ of the sample earn above Rs 20,000. As far as geographical profile is concerned, 55\% of the respondents stay in villages while the remaining $45 \%$ are inhabitants of towns. 


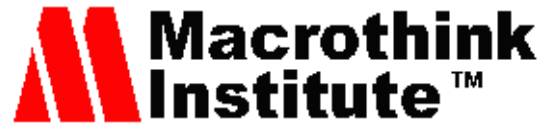

\subsubsection{Budgeting}

This practice was common among the majority of the respondents (61.7\%). This provides preliminary evidence that households want to be in control of their finances and also want to plan for the future .Out of the respondents who do prepare budgets, 64 respondents prepare a plan on a monthly basis. It can be inferred that domestic budgetary control is of much significance to Mauritian households. In addition, results concur with findings of Kempson (1993) that the choice of the budgeting period is strongly influenced by the frequency with which earnings are received and that the choice of the budgeting period is also linked to occupational status. Moreover, it is found that more than $80 \%$ of houses do not prepare a detailed written budget, indicating that cash accounting prevails over accruals basis of accounting. Northcott and Doolin (2000) argue that some households construct very detailed budget while others make use of budgets with fewer details or just mentally make account of what is available to spend monthly. Respondents who do not prepare budgets aver that they find the task time consuming and they do not feel the need for budgeting.

\subsubsection{Record keeping}

A wide majority of respondents (86. $7 \%$ ) claim keeping financial records such as bills and bank statements. These findings provide evidence that the objective of record keeping is in line with accounting objective which is for reference purposes. Findings would suggest that households understand the importance of maintaining proper financial records which can assist in future spending and financial planning. Furthermore, out of respondents who do keep financial records, $65.4 \%$ of households do so for taxation purposes. This can be explained by the fact that proper records could ease tax calculation and shorten the time for an income tax refund. This is in line with findings of Northcott and Doolin (2000). Results also reveal that the habit of computerised recording of documents is not yet present in Mauritius as shown by the $86.5 \%$ disagreement. This may be mainly attributed to the fact that the use of computers is not widespread in Mauritian homes. Moreover, computers are not viewed as a medium of using accounting practices as the various software are barely known in Mauritians.

\subsubsection{Decision Making}

Normally when a considerable amount of money is involved, the decision-making process becomes more important. The vast majority of households agree with this matter; only $4.2 \%$ disagrees. These results concur with those of Janudin and Mohamad (2005) who argue that decisions become more important when greater amount is involved.

In addition, respondents were asked to identify the criteria that were considered most important in decision making processes. Cash availability, followed by price were the two most important factors identified by household accountants. This is in line with findings of Janudin and Mohamad (2005) who assert that the main decisive factor was based on cash flows so as to avoid being indebted. This explanation can be justified by the factor "accessibility of credit facilities" which is deemed relevant in only 42 cases; these figures again emphasise the fact that people do not like being indebted. 


\section{Al Macrothink}

International Journal of Accounting and Financial Reporting

ISSN 2162-3082 2016, Vol. 6, No. 2

\subsubsection{Long term financial Planning}

About 57\% of houses engaged in long term financial planning. Outof these 68 respondents only 40 plan for 6 months to 1 year period, while only 40 households plan for 1-4 years. It can be claimed that long term financial planning is the least practised among home accountants. This is in line with findings of Northcott and Doolin (2000) who argue that this practice was the least evident among interviewees and that their short terms focus reduced their tendency to engage in long term financial planning.Findings contrast with economic life cycle ideas or permanent life cycle hypothesis of financial management. One possible explanation could be that "home life is unlike the going concern context of business enterprises." This would also entail that households have short-term preference that decrease their propensity to be involved in long term financial planning.

\subsection{Factor Analysis}

\begin{tabular}{|c|c|c|c|c|c|c|}
\hline Table 3: & Results for Factor Analysis & & & & & \\
\hline & & 1 & 2 & 3 & Mean & Std. Dev \\
\hline \multirow[t]{2}{*}{ Budgeting } & Allocating income for expenses is easier & & 0.816 & & 1.84 & 0.722 \\
\hline & Identify opportunities for savings and investment & & 0.713 & & 1.8 & 0.74 \\
\hline \multirow{7}{*}{$\begin{array}{l}\text { Planning } \\
\text { and } \\
\text { decision } \\
\text { making }\end{array}$} & Plan for the future & 0.625 & & & 1.77 & 0.742 \\
\hline & Provide a sense of financial security & 0.652 & & & 2.1 & 0.749 \\
\hline & Reduce financial stress & 0.673 & & & 2.47 & 0.879 \\
\hline & Spot where unnecessary expenditure has occurred & 0.523 & & & 2.08 & 0.784 \\
\hline & Decision on financial matters can be made quickly & 0.485 & & & 2.28 & 0.852 \\
\hline & Make ends meet & 0.76 & & & 2.46 & 0.907 \\
\hline & Notify the family leader to the likelihood of falling into debt & 0.623 & & & 2.5 & 0.987 \\
\hline \multirow{2}{*}{\begin{tabular}{|l|} 
No \\
perceived \\
benefits
\end{tabular}} & Time-consuming & & & 0.754 & 2.78 & 1.033 \\
\hline & Do not serve anything & & & 0.766 & 3.94 & 0.863 \\
\hline
\end{tabular}

The aim of this analysis is to group the 11 variables representing benefits and drawbacks of household accounting into underlying dimensions. The Kaiser-Meyer-Olkin (KMO) value reached 0.749 which is considered excellent for factor analysis (Kaiser, 1974). The Barlett test of sphericity reached statistical significance (0.000) indicating that factor analysis is appropriate. According to the Kaiser principle, only those factors with eigen values greater than 1 were maintained for further analysis. Principal Component Analysis revealed the presence of three factors which together explain a variance of 53\%. A clear structure emerged after reducing the variables to three factors. A varimax rotation was performed to reorganise the three components. As a general rule factor, loadings less than 0.4 have been suppressed. The variables were listed in Table 3 , in the order of size of their factor loadings. Factor 1 provides evidence of 'budgeting', factor 2 was named 'planning and decision making' and factor 3 showed that respondents 'perceived no benefits' from household accounting. Two of the three factors outlines the benefits of household accounting and have greater factor loadings which imply that household accounting brings more benefits than drawbacks to respondents. This is also confirmed by the means of the statements. The highest means are attributed to 'No perceived benefits'. 
In addition, as can be seen from the table, the first three options having lower means, it can be inferred that respondents want to be in control of their personal finances. This corresponds with findings of Livingstone and Lunt (1993). One reason justifying this situation is that since people record their incomes and expenses, they are in a position to know exactly the amount they are receiving and their likely outflows. They can consequently undertake a proper planning whereby the available income will be apportioned to meet the different expenses. The risk of falling into debt owing to expenses not paid is also reduced. Moreover, families can decide the purposes to which excess funds will be put to, based on circumstances they expect to prevail in the future. It can also be averred that being in control of their financial affairs, households enjoy a greater sense of security.

We also observe that home accountants enjoy considerable other benefits of household accounting such as a sense of financial security, reduction of financial stress, identifying areas for more prudent spending and so on. As far as drawbacks are concerned, one would have expected time constraints and impracticality of accounting practices to be of a hindrance as suggested by literature. However, Mauritian households do not perceive these factors as an impediment to household accounting. This may be explained by the fact that the advantages of home accounting far exceed its cost, as is also established by the factor analysis. Furthermore, being in control of one's financial affairs makes the preparationof tax returns easy and accurate also provides the household with a sense of financial control.

\subsection{Results of hypothesis testing}

The first hypothesis states that there will be a relationship between household accounting and level of education. The Pearson correlation was used to test this hypothesis. Results for the independent variable show no significant relationship with the dependent variable. Therefore the hypothesis is rejected, that is there is no significant relationship between level of education and household accounting. One possible explanation is that accounting is very much connected with our personal lives in so far as it is in respect of very business. This is regardless of the level of education one has achieved. It is also believed that one deliberately or inadvertently generates accounting ideas when one plans what has to be done with their finances. This is irrespective of educational level.This is in contrast to findings of Phal (2000) who suggests that couples with higher level of education were more particularly associated with advanced accounting patterns.

The second hypothesis proposes that there is a relationship between household accounting and level of income. The Chi-square statistic show that the hypothesis is supported at $10 \%$ significance level that is the practice of household accounting is indeed influenced by income. Further analysis of the table above shows that people at the lower end of the income ladder are more prone to use household accounting, which is in accord with the findings of Pahl (2000). For instance, $70 \%$ of people earning a salary of less that Rs 15,000 are involved in household accounting. It is interesting to note that the number of non-users of household accounting is more prevalent in the highest income category. Probably these people can meet the two ends and are complacent about their situation. Consequently they find no use in preparing budgets. 


\section{Mll Macrothink}

International Journal of Accounting and Financial Reporting

ISSN 2162-3082

2016, Vol. 6, No. 2

As regards hypotheses 3 and 4, it was found that there are no significant relationship between household accounting, gender and geographical location with p values of 0.207 and 0.577 respectively. While research in gendered differentiation provides mixed results, no such disparity has been found in Mauritius. This can be explained by gender equality in Mauritius. In addition, this can also be explained by the recent empowerment of women and the positive tradeoff between the augmentation of educated women and the increase of the presence of women in work place, both in the public sector or within entrepreneurial activities. Results are consistent with studies of Komori and Humphrey, (2000), Walker (1998) and Carnegie and Walker (2007b). As far as geographical location is concerned, results can be explained by the fact that there is insignificant disparity between urban and rural areas in Mauritius. This may be due to the recent urbanisation process in Mauritius.

\subsection{Factors influencing household accounting}

This section identifies the factors which inspired home accountants to use accounting methods at home. 7 factors had been identified. It was seen that the most important reasons which have been put forward are parental influence, reducing indebtedness, for taxation purposes and important events such as birth, death and marriage with a mean of 2.4, 1.75, 1.79 and 2.03 respectively.

As far as parental influence is concerned, this can be justified by the advantages which the use of accounting methods yielded to their parents. These results comply with those of Northcott and Doolin (2000) who contend that many interviewees had accepted that their home accounting reflected the practices and attitudes of their parents. Ideas to home financial management was often learned from parents or was deliberately transmitted to children.

The avoidance of overspending or indebtedness may be explained by the fact that people are incredibly concerned about overspending and using accounting methods such as budgeting and record-keeping may prevent them from spending money on unnecessary items and hence the use of household accounting. Being indebted may be viewed as being in a precarious condition, lessening the notion of financial security and control. Thus households would make use of accounting tools to decrease the risk of debt. Besides, the respondents could perceive accounting practices as a means by which money could be put aside at regular intervals to invest an item which would otherwise have required a loan.

The calculation of tax requires recording expenses and incomes during the tax year. Recordkeeping enables appropriate filling of tax forms or minimising the tax amount to be paid. Incorrectly filled forms lead to payment of penalty fees. With all information about incomes and expenses readily available, tax computation is not time-consuming. Northcott and Doolin (2000) also attest that accounting records are kept for tax reasons.

A marriage in the family normally requires considerable sums of money. The members eventually start keeping money aside for the arrangements by proper budgeting and planning, for example, reducing expenses or avoiding unnecessary expenses much before the event. The same applies for birth; parents may have recourse to long term financial planning where they start to save for a child's future. As regards the event of death, especially if it concerns a 


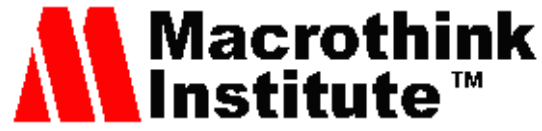

International Journal of Accounting and Financial Reporting ISSN 2162-3082 2016, Vol. 6, No. 2

widow whose working husband has died, the widow is left to cater for the whole family's needs. As income will be limited, the widow may have to reduce expenses or even resort to budgeting to ensure that all the wants and needs of the family are fulfilled and also to lead a financially secure life. Sharing the same view, Walker and Llewellyn (2000) claim that crucial events in life may lead to the commencement of household and personal accounting while Connor (2004) avers that widowhood has long been acknowledged as a catalyst for home accounting.

\section{Conclusions}

Diverse studies conducted have proved that accounting does have a role to play in the privacy of the homes and the home is increasingly a significant domain for accounting research. While all four categories of accounting namely budgeting, record-keeping, decision making and long-term financial planning were apparent practices, we find that long term financial planning was the least evident. What also emerges from the study is the strong aversion to debt and a high desire to be in control of home finance. The availability of cash was the main factor influencing decision making .Simple accounting records such as bills and bank statements were kept by household accountants for reference purposes.

While different factors which motivate the use of household accounting have been established, parental influence, risk averseness, tax planning and important events such as birth, death and marriage were the most prominent factors. The various benefits of engaging in home accounting have also been established. In addition, the study could not establish any relationship between gender and household accounting, explained due to the egalitarian nature of the Mauritian society.

From the findings, it was established that computers have very little role in household accounting in Mauritius. However, in other countries, the owners of personal computers have replaced their manual systems of household accounts by home finance software. Applications such as Microsoft Money, House Hold Accounting for Windows and Quicken offer new scope to household accounting and the relationships between those family members who input and use financial data (The Times, July 1997). Using computer for preparing accounts may enable household accounting to be less time-consuming. Records can be kept for a very long time while ensuring that data will not be lost. Furthermore, reference to previous expenses can be made quicker.

The Malaysian Government started emphasising the importance of household accounting through the introduction of Pocket Money Book and Planning and Household Account Book in 2004. The Malaysian Government through these books aimed at increasing public awareness on the importance of management of personal finances and financial planning. Another such attempt has been made in Germany since January 1996 through the distribution of The New Household Accounting Book, The Euro-Budget-Planning-System and My Pocket Money. These household accounting systems designed to support financial management and budget administration appear to have met with some success (Piorkowsky\&FriedrichWilhelms, 2000). The Pocket Money Book is perceived as encouraging both financial management and budget administration among children. Regular users of the New Household 


\section{Macrothink}

International Journal of Accounting and Financial Reporting

ISSN 2162-3082

2016, Vol. 6, No. 2

Accounting Books assert that they have not suffered "money trouble" since using them. The government of Mauritius may likewise promote household accounting through distributing books based on this subject to school children or to the general public.

Finally, there are some limitations on relying entirely on these findings. This research is perhaps the only one in Mauritius that analyses the accounting practices of Mauritians in day to day domestic financial practices. Various other studies will have to be conducted to form any generalised statements. Furthermore, the study only concerted 120 Mauritian households. To reach a more appropriate conclusion on the accounting practices of Mauritians, a larger sample may be considered. This would increase the reliability of the findings as a wider variety of opinions could be obtained. While only precursory in nature, this study has highlighted the important role of accounting in Mauritian households. It also provides preliminary evidence that household accounting is a significant area of research.

\section{References}

Berthoud, R. and Kempson, E. (1992). Credit and Debt: The PSI Report, Policy Studies Institute,London.

Carnegie, G.D. and Walker, S.P. (2007a). Household accounting in Australia: prescription andpractice from the 1820s to the 1960s. Accounting, Auditing \& Accountability Journal,

Vol. 20 No. 1, pp. 41-73.

Carnegie, G.D. and Walker, S.P. (2007b). Household accounting in Australia: a microhistoricalstudy. Accounting, Auditing \& Accountability Journal, Vol. 20 No. 2, pp. 21036.

Chowa, G. A. N. (2006). Savings performance among rural households in Sub SaharanAfrica: The effect of Gender. Social Development Issues, 28(2), 106 - 116.

Connor, R.E. (2004). Women, Accounting, and Narrative. Keeping Books in EighteenthCentury England, Routledge, London.

Fagerberg, D. (1954).Spotlight on personal accounting. The Accounting Review, pp. 355-64.

Froud J., Haslam C., Johal S. and Williams K. (2000).Representing the household: in and after national income accounting.Accounting, Auditing \& Accountability Journal,, Vol. 13 (4): 535-60

Haskins \& Sells (1984). Our First Seventy-Five Years. Garland Publishing, New York, NY.

Hopper, J. S. (1995). Family financial decision making : implications for marketing

Strategy. Journal of Services Marketing, Vol 9 (1)

Hopwood, A.G. (1994). Accounting and everyday life: an introduction. Accounting, Organizations and Society, pp. 299-301. 


\section{Macrothink}

International Journal of Accounting and Financial Reporting

ISSN 2162-3082

2016, Vol. 6, No. 2

Janudin S.E. and Mohamad A.R. The art of household accounting practice in Malaysia: an exploratory study' study.[online] (Accessed 12 September 2008) Available from <URL:http://icbm.bangkok.googlepages.com/38.Sharul.Effendy.Janudin.PAR.pdf>

Kaiser, H. (1974). An index of factorial simplicity. Psychometrika, 39, 31-36.

Kempson,E (1993). Household budgets and housing costs. Policy Studies Institue,London

Komori, N., Humprey, H. (2000).From an envelope to a dream note and computer, The award-winning experiences of post war Japanese household accounting practices. Accounting, Auditing \& Accountability Journal, Vol 13(4), 450 - 474

Levy, R.J. (1989). An introduction to divorce-property issues. Family Law Quarterly, Vol. XXIII,No. 2, Summer, pp. 147-62.

Livingstone, S. and Lunt, P. (1993). Savers and borrowers: strategies of personal financialmanagement. Human Relations, Vol. 46 No. 8, August, pp. 963-85.

Llewellyn, S. and Walker, S.P. (2000b). Household accounting as an interface activity: the home,the economy and gender. Critical Perspectives on Accounting, Vol. 11 No. 4, pp. 44778 .

McRae, T.W. (1997). Managing Your Own Finances. International Thomson Business Press,

London.

National Economic and Social Council report .Managing Indebtedness and Household Budgets for Better Living. April 2011

Nickell, P., Rice, A.S. and Tucker, S.P. (1976). Management in Family Living. John Wiley \& Sons,New York, NY.

Northcott, D, Doolin, B (2000). Home Accountants: Exploring their practices. Accounting, Auditing \& Accountability Journal, Vol 13(4), 475 - 501

Oppenheim, I. (1976), Management of the Modern Home, Macmillan Publishing Co., New York,NY.

Pahl, J. (2000). Couples and their money: patterns of accounting and accountability in the domestic economy. Accounting, Auditing \& Accountability Journal,Vol 13(4), 502 -517

Piorkowsky, M. B. (2000). Household Accounting in Germany, Some statisticalevidence and the development of new systems. Accounting, Auditing \&Accountability Journal, Vol 13(4), $518-534$

Thaler, R.H. (1992). The Winner's Curse: Paradoxes and Anomalies of Economic Life. PrincetonUniversity Press, Princeton, NJ.

The Times Magazine, July, 1997 


\section{Macrothink}

International Journal of Accounting and Financial Reporting

ISSN 2162-3082

Walker, S.P. (1998). How to secure your husband's esteem: accounting and private patriarchy inthe British middle class household during the nineteenth century. Accounting,

Organizations and Society, Vol. 23 Nos 5/6, August, pp. 485-514.

Walker S.P. and Llewellyn S. (2000). Accounting at Home: some interdisciplinary perspectives. Accounting, Auditing \& Accountability Journal, Vol. 13 No. 4, pp. 425-49.

Whyley, C., Kempson, E. and Herbert, A. (1997). Money Matters: Approaches to Money

Management and Bill Paying. Policy Studies Institute, London.

Wood, F. (2005). Business Accounting 1:10 Edition, Prentice Hall:UK

\section{Copyright Disclaimer}

Copyright for this article is retained by the author(s), with first publication rights granted to the journal.

This is an open-access article distributed under the terms and conditions of the Creative Commons Attribution license (http://creativecommons.org/licenses/by/3.0/). 